\title{
Robotic surgery in urology: the way forward
}

\author{
Riccardo Autorino $^{1}$ · Francesco Porpiglia ${ }^{2}$ \\ Published online: 19 March 2020 \\ (c) Springer-Verlag GmbH Germany, part of Springer Nature 2020
}

Keywords Adrenalectomy $\cdot$ Fluorescence $\cdot$ Lymph node dissection $\cdot$ Prostatectomy $\cdot$ Radical cystectomy $\cdot$ Single port . Robotic surgery $\cdot$ Technology $\cdot 3 \mathrm{D}$ imaging

The idea of robotic intervention in medicine is not recent. In 1960, a preliminary report on robotic angiography was published [1]. In the late 1980s, applications of robotic stereotactic neurosurgery were explored [2]. In the early 1990s, there were early experiences with robotic-assisted laparoscopy [3], and during the same period, the first "urologic" robotic system - the Probot—was described by investigators from the Imperial College in London with the purpose of performing transurethral prostate resections $[4,5]$. A decade later, at the dawn on the new century, French and German groups reported the first cases of robotic assisted laparoscopic radical prostatectomy using the first generation DaVinci system [6,7], and soon after the world's first robotic prostate cancer surgery program was established by Dr. Menon and his team in Detroit [8].

Since then, while radical prostatectomy has remained the bulk of robotic procedures in Urology [9], other oncology and non-oncology indications have been explored [10]. As robotic technology is being rapidly implemented in different surgical specialties, with Urology in the forefront of this phenomenon [11], evidence supporting its use continues to build up (Fig. 1), while ongoing debate related to increases costs [12] and need for structured training [13] remain.

In this special issue of the World Journal of Urology, we collected a series of reports from leading institutions in the field on hot topics in robotic urologic surgery. The idea was to fuel the debate on key clinical questions by providing

Riccardo Autorino

ricautor@gmail.com

1 Division of Urology, Department of Surgery, VCU Health, 980118, Richmond, VA 23298-0118, USA

2 Division of Urology, Department of Oncology, School of Medicine, San Luigi Hospital, University of Turin, Orbassano, Italy the readers with interesting (and in some cases provocative) readings on the latest developments in the field.

In the area of prostate surgery, risk of positive margins remains an issue [14], and Cumarasamy et al. present a model based on preoperative variables to predict this risk [15]. Moreover, robotic surgery has "revived" the perineal approach for radical prostatectomy [16], and Kaouk and collaborators present an overview on the recent advances based on their experience with robotic perineal prostatectomy [17]. As robotic surgery is being implemented for the surgical treatment of benign prostatic hyperplasia [18], Hemal et al. describe a novel radical prostatectomy for patients with low risk cancer and enlarged prostate gland [19].

In the area of bladder surgery, robotic assisted techniques are gaining momentum, but they are still under scrutiny [20]. Brassetti et al. report one of the largest series with long-term data about robot-assisted radical cystectomy with totally intracorporeal urinary diversion [21].

As the role of robotic nephroureterectomy for upper urothelial cancer remains under scrutiny, Veccia et al. report a systematic review and meta-analysis of comparative outcomes versus more established nephroureterectomy techniques [22]. Robotic surgery is also being explored for adrenal surgery [23], and Ye et al. describe a novel adrenal enucleation technique [24]. Moreover, the robotic platform has allowed to replicate in quality and extent lymph node dissections for several genitourinary cancers [25], and a leader group in the field report one of the largest series of primary robotic retroperitoneal lymph node dissection for non-seminomatous germ cell testicular cancer [26].

As we enter the era of precision surgery [27], the role of robotic-assisted procedures is here to stay, and surgery applications of robotic technology are expanding and consolidating. Integration of novel technologies will further boost this process, and image guidance will represent a key tool in the hands of the console surgeon. In this respect, 


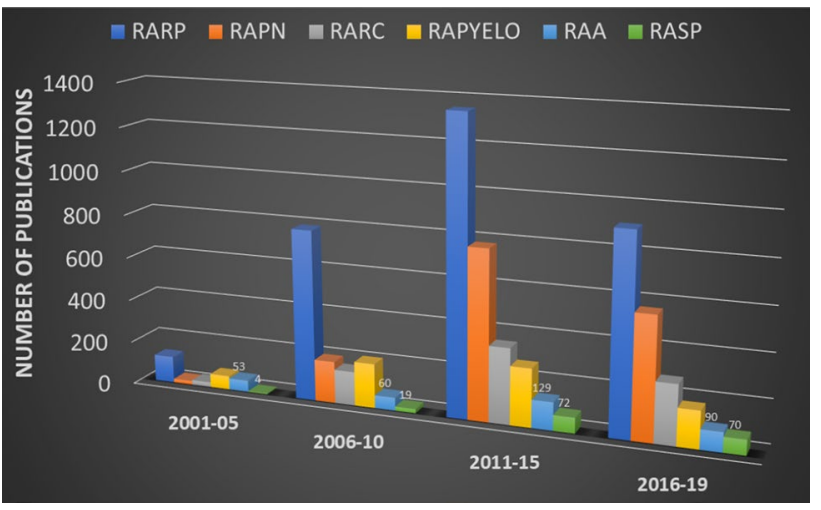

Fig. 1 Scopus-based literature trend analysis on index robotic surgical procedures in Urology (years 2001-2019). RARP robotic assisted radical prostatectomy, $R A P N$ robotic assisted partial nephrectomy, $R A R C$ robotic assisted radical cystectomy, RAPYELO robotic assisted pyeloplasty, $R A A$ robotic assisted adrenalectomy, $R A S P$ robotic assisted simple prostatectomy

Checcucci et al. provide a comprehensive overview of 3D imaging technology [28], whereas Cacciamani et al. report current best practices in near-infrared fluorescence imagingguided robotic surgery [29].

Last, the advent of new systems is awaited to enrich the current robotic armamentarium [30]. The DaVinci SP ${ }^{\mathrm{TM}}$ port platform just entered the market in the US, will soon be available in Europe, and it is likely to foster renewed interest for single port surgery [31]. Dobbs et al. describe their initial clinical experience with this platform [32]. We eagerly await new developments in the field, and it is our responsibility to stay tuned.

\section{References}

1. Veiga-Pires JA, Godfrey BE (1960) Robot angiography. A preliminary report. Lancet 2(7149):542-544 (PubMed PMID: 13841561)

2. Young RF (1987) Application of robotics to stereotactic neurosurgery. Neurol Res 9(2):123-128 (PubMed PMID: 2886941)

3. Gagner M, Begin E, Hurteau R, Pomp A (1994) Robotic interactive laparoscopic cholecystectomy. Lancet 343(8897):596-597 (PubMed PMID: 7906340)

4. Davies BL, Hibberd RD, Coptcoat MJ, Wickham JE (1989) A surgeon robot prostatectomy-a laboratory evaluation. J Med Eng Technol 13(6):273-277 (PubMed PMID: 2614807)

5. Harris SJ, Arambula-Cosio F, Mei Q, Hibberd RD, Davies BL, Wickham JE, Nathan MS, Kundu B (1997) The Probot-an active robot for prostate resection. Proc Inst Mech Eng H 211(4):317325 (PubMed PMID: 9330543)

6. Binder J, Kramer W (2001) Robotically-assisted laparoscopic radical prostatectomy. BJU Int 87(4):408-410 (PubMed PMID: 11251539)

7. Abbou CC, Hoznek A, Salomon L, Olsson LE, Lobontiu A, Saint F, Cicco A, Antiphon P, Chopin D (2001) Laparoscopic radical prostatectomy with a remote controlled robot. J Urol 165(6 Pt 1):1964-1966 (PubMed PMID: 11371890)

8. Menon M, Shrivastava A, Tewari A, Sarle R, Hemal A, Peabody JO, Vallancien G (2002) Laparoscopic and robot assisted radical prostatectomy: establishment of a structured program and preliminary analysis of outcomes. J Urol 168(3):945-949 (PubMed PMID: 12187196)

9. Barbash GI, Friedman B, Glied SA, Steiner CA (2014) Factors associated with adoption of robotic surgical technology in US hospitals and relationship to radical prostatectomy procedure volume. Ann Surg 259(1):1-6. https://doi.org/10.1097/SLA.0b013e3182 a5c8b8(PubMed PMID: 23965894)

10. Autorino R, Zargar H, Kaouk JH (2014) Robotic-assisted laparoscopic surgery: recent advances in urology. Fertil Steril 102(4):939-949. https://doi.org/10.1016/j.fertnstert .2014.05.033(Epub 30 Jun 2014. Review. PubMed PMID: 24993800)

11. Juo YY, Mantha A, Abiri A, Lin A, Dutson E (2018) Diffusion of robotic-assisted laparoscopic technology across specialties: a national study from 2008 to 2013. Surg Endosc 32(3):1405-1413. https://doi.org/10.1007/s00464-017-5822-4(Epub 25 Aug 2017. PubMed PMID: 28842801)

12. Dobbs RW, Magnan BP, Abhyankar N, Hemal AK, Challacombe B, Hu J, Dasgupta P, Porpiglia F, Crivellaro S (2017) Cost effectiveness and robot-assisted urologic surgery: does it make dollars and sense? Minerva Urol Nefrol 69(4):313-323. https:// doi.org/10.23736/S0393-2249.16.02866-6(Epub 22 Dec 2016. Review. PubMed PMID: 28008756)

13. Palagonia E, Mazzone E, De Naeyer G, D'Hondt F, Collins J, Wisz P, Van Leeuwen FWB, Van Der Poel H, Schatteman P, Mottrie A, Dell'Oglio P (2019) The safety of urologic robotic surgery depends on the skills of the surgeon. World J Urol. https://doi. org/10.1007/s00345-019-02901-9(Epub ahead of print. PubMed PMID: 31428847)

14. Zhang L, Wu B, Zha Z, Zhao H, Yuan J, Jiang Y, Yang W (2018) Surgical margin status and its impact on prostate cancer prognosis after radical prostatectomy: a meta-analysis. World J Urol 36(11):1803-1815. https://doi.org/10.1007/s00345-018-23334(Epub 15 May 2018)

15. Cumarasamy S, Martini A, Falagario UG, Gul Z, Beksac AT, Jayaratna I, Haines GK 3rd, Carrieri G, Tewari A (2020) Development of a model to predict prostate cancer at the apex (PCAP model) in patients undergoing robot-assisted radical prostatectomy. World J Urol. https://doi.org/10.1007/s00345-019-02905-5

16. Akca O, Zargar H, Kaouk JH (2015) Robotic surgery revives radical perineal prostatectomy. Eur Urol 68(2):340-341. https://doi. org/10.1016/j.eururo.2015.03.001(Epub 23 Mar 2015. PubMed PMID: 25813693)

17. Garisto J, Bertolo R, Wilson CA, Kaouk J (2020) The evolution and resurgence of perineal prostatectomy in the robotic surgical era. World J Urol. https://doi.org/10.1007/s00345-019-03004-1

18. Meyer D, Weprin S, Zukovski EB, Porpiglia F, Hampton LJ, Autorino R (2018) Rationale for robotic-assisted simple prostatectomy for benign prostatic obstruction. Eur Urol Focus 4(5):643647. https://doi.org/10.1016/j.euf.2018.07.007(Epub 20 Jul 2018. PubMed PMID: 30033068)

19. Pathak RA, Hemal AK (2020) Management of low-risk prostate cancer in patients with enlarged glands and lower urinary tract symptoms: robotic total prostatectomy, a novel technique. World J Urol. https://doi.org/10.1007/s00345-019-02951-z

20. Tyritzis SI, Gaya JM, Wallestedt-Lantz A et al (2019) Current role of robotic bladder cancer surgery. Minerva Urol Nefrol 71(4):301-308. https://doi.org/10.23736/S0393-2249.19.03435 -0(Epub 7 May 2019. PubMed PMID: 31086134)

21. Brassetti A, Cacciamani G, Anceschi U et al (2020) Long-term oncologic outcomes of robot-assisted radical cystectomy (RARC) 
with totally intracorporeal urinary diversion (ICUD): a multicenter study. World J Urol. https://doi.org/10.1007/s00345-01902842-3

22. Veccia A, Antonelli A, Francavilla S et al (2020) Robotic versus other nephroureterectomy techniques: a systematic review and meta-analysis of over 87,000 cases. World J Urol. https://doi. org/10.1007/s00345-019-03020-1

23. Pavan N, Derweesh I, Rassweiler J, Challacombe B, Zargar H, Porter J, Liatsikos E, Kaouk J, Porpiglia F, Autorino R (2017) Contemporary minimally invasive surgery for adrenal masses: it's not all about (pure) laparoscopy. BJU Int 119(2):201-203. https:// doi.org/10.1111/bju.13701

24. Ye C, Yang Y, Guo F, Wang F, Zhang C, Yang B (2020) Robotic enucleation of adrenal masses: technique and outcomes. World $\mathbf{J}$ Urol. https://doi.org/10.1007/s00345-019-02868-7(Epub ahead of print. PubMed PMID: 31292732)

25. Pini G, Matin SF, Suardi N, Desai M, Gill I, Porter J, Stein RJ, Sotelo R, Gaboardi F, Porpiglia F (2017) Robot assisted lymphadenectomy in urology: pelvic, retroperitoneal and inguinal. Minerva Urol Nefrol 69(1):38-55. https://doi.org/10.23736/S0393 -2249.16.02823-X(Epub 8 Nov 2016. Review. PubMed PMID: 28009144)

26. Rocco NR, Stroup SP, Abdul-Muhsin HM et al (2020) Primary robotic RLPND for nonseminomatous germ cell testicular cancer: a two-center analysis of intermediate oncologic and safety outcomes. World J Urol. https://doi.org/10.1007/s00345-019-02900 $-\mathrm{W}$

27. Autorino R, Porpiglia F, Dasgupta P, Rassweiler J, Catto JW, Hampton LJ, Lima E, Mirone V, Derweesh IH, Debruyne FMJ (2017) Precision surgery and genitourinary cancers. Eur J Surg Oncol 43(5):893-908. https://doi.org/10.1016/j.
ejso.2017.02.005(Epub 20 Feb 2017. Review. PubMed PMID: 28254473)

28. Checcucci E, Amparore D, Fiori C et al (2020) 3D imaging applications for robotic urologic surgery: an ESUT YAUWP review. World J Urol. https://doi.org/10.1007/s00345-019-02922-4(Epub ahead of print. PubMed PMID: 31456017)

29. Cacciamani GE, Shakir A, Tafuri A et al (2020) Best practices in near-infrared fluorescence imaging with indocyanine green (NIRF/ICG)-guided robotic urologic surgery: a systematic reviewbased expert consensus. World J Urol. https://doi.org/10.1007/ s00345-019-02870-z(Epub ahead of print. PubMed PMID: 31286194)

30. Rassweiler JJ, Autorino R, Klein J, Mottrie A, Goezen AS, Stolzenburg JU, Rha KH, Schurr M, Kaouk J, Patel V, Dasgupta P, Liatsikos E (2017) Future of robotic surgery in urology. BJU Int 120(6):822-841. https://doi.org/10.1111/bju.13851

31. Kaouk JH, Haber GP, Autorino R, Crouzet S, Ouzzane A, Flamand V, Villers A (2014) A novel robotic system for single-port urologic surgery: first clinical investigation. Eur Urol 66(6):10331043. https://doi.org/10.1016/j.eururo.2014.06.039(Epub 17 Jul 2014. PubMed PMID: 25041850)

32. Dobbs RW, Halgrimson WR, Talamini S, Vigneswaran HT, Wilson JO, Crivellaro S (2019) Single port robotic surgery: the next generation of minimally invasive urology. World J Urol. https:// doi.org/10.1007/s00345-019-02898-1

Publisher's Note Springer Nature remains neutral with regard to jurisdictional claims in published maps and institutional affiliations. 